\title{
On Sidgwick's Demise: A Reply to Professor Deigh
}

\author{
ANTHONY SKELTON \\ The University of Western Ontario
}

\begin{abstract}
In 'Sidgwick's Epistemology', John Deigh argues that Henry Sidgwick's The Methods of Ethics 'was not perceived during his lifetime as a major and lasting contribution to British moral philosophy' and that interest in it declined considerably after Sidgwick's death because the epistemology on which it relied 'increasingly became suspect in analytic philosophy and eventually [it was] discarded as obsolete'. In this article I dispute these claims.
\end{abstract}

In a recent article in this journal, John Deigh ${ }^{1}$ argues that Henry Sidgwick's The Methods of Ethics ' 'was not perceived during his lifetime as a major and lasting contribution to British moral philosophy' (438), and that interest in it declined considerably after Sidgwick's death because the epistemology on which it relied increasingly became suspect in analytic philosophy and eventually [it was] discarded as obsolete' (439). In this article I dispute these claims.

Deigh argues that Sidgwick's Methods 'was not perceived during his lifetime as a major and lasting contribution to British moral philosophy' (438). However, this is far from clear. First, to make his point Deigh relies on an article in Encyclopaedia Britannica and an obituary in Mind by Leslie Stephen. ${ }^{3}$ These are not decisive. Stephen announces at the outset of his obituary that he is not concerned to provide an estimate of Sidgwick's work in philosophy, though he notes that Methods is a 'great book' and that Sidgwick's work in ethics gave 'the most important of all modern contributions towards a clear realisation of the conditions of approaching the problems involved'. ${ }^{4}$ The encyclopaedia article does not deny that Methods is a major contribution; instead, it merely fails to single it out. ${ }^{5}$ Second, a number of important philosophers were sent copies of Methods when the first edition was published in 1874,

\footnotetext{
1 John Deigh, 'Sidgwick's Epistemology', Utilitas 19 (2007), pp. 435-46. All bare parenthetical references in the text are to this work.

${ }^{2}$ Henry Sidgwick, The Methods of Ethics, 7th edn. (London, 1907). Hereinafter ME.

${ }^{3}$ Encyclopaedia Britannica, 9th-10th edns. (London, 1903), vol. 32, p. 618 and Leslie Stephen, 'Henry Sidgwick', Mind 10 (1901), pp. 1-17.

4 Stephen, 'Henry', pp. 7 and 15.

${ }^{5}$ I owe the point in this sentence to Robert Shaver.
} 
including John Caird, J. E. Carines, Alexander Bain and T. R. Birks. All praised the book. In a letter thanking Sidgwick for a copy of Methods, Bain claimed that 'no work in Ethics ever impressed me so much' and that what will make the work 'live' is the 'triumphant way that Utility is erected in the basis of Common Sense'. ${ }^{6}$ Although he had not read Methods in its entirety, when Cairnes wrote to thank Sidgwick for his copy he claimed that the writing was a 'rare treat'.

Third, the praise continued in various reviews. Henry Calderwood declared that despite his misgivings about Sidgwick's account of intuitionism the latter had 'rendered a great service to Intuitionalism by the line of criticism he has followed in treating of the several virtues' and that he admired 'the ability manifest everywhere throughout the book'. ${ }^{8}$ Alexander Bain maintained that it is 'one of the best volumes of the present generation' and that it is a 'great work'. ${ }^{9}$ To an article on Methods by Alfred Barratt in Mind the editor attached a note stating that the interest that 'continues to be excited by The Methods of Ethics ... is a notable fact in English philosophy at the present day, and there should remain due record of it in the pages of this Journal'. ${ }^{10}$ In his critical notice of the third edition of Methods, Hastings Rashdall claimed that the work 'has long been recognised as a philosophical classic' and that

It is one of those books of which it is safe to prophesy that no advance in philosophic doctrine will ever render them obsolete. It is not merely a piece of acute and subtle philosophical criticism but a work of art with a unity and beauty of its own as much as a Dialogue of Plato or of Berkeley. ${ }^{11}$

In his review of the fourth edition of Methods, G. von Gizycki writes that 'few books deserve to the same degree as this to be recommended to students of ethics; for few to a like degree constrain us to clear and exact thinking. ${ }^{12}$

Fourth, during Sidgwick's lifetime a number of important moral philosophers took pains to come to grips with Methods. T. H. Green devoted considerable attention to Sidgwick's views in Prolegomena to Ethics. ${ }^{13}$ F. H. Bradley devoted both a small part of Ethical Studies

\footnotetext{
${ }^{6}$ Sidgwick Papers, Wren Library, Trinity College, Cambridge University, Add.Ms.c.93.22.

7 Sidgwick Papers, Wren Library, Trinity College, Cambridge University, Add.Ms.c.93.71.

8 Henry Calderwood, 'Mr. Sidgwick on Intuitionalism', Mind 1 (1876), p. 206.

9 Alexander Bain, 'Mr. Sidgwick's Methods of Ethics', Mind 1 (1876), pp. 185 and 195.

10 Alfred Barrett, 'The “Suppression” of Egoism', Mind 2 (1877), p. 167n.

11 Hastings Rashdall, 'Professor Sidgwick's Utilitarianism', Mind 10 (1885), p. 200.

12 G. von Gizycki, Review of The Methods of Ethics, 4th edn., International Journal of Ethics 1 (1890), p. 120.

${ }_{13}$ T. H. Green, Prolegomena to Ethics, ed. David Brink (Oxford, 2003). See especially $\S \S 364-82$.
} 
and a whole pamphlet, Mr. Sidgwick's Hedonism, to Methods. ${ }^{14}$ Herbert Spencer dealt at length in The Data of Ethics with some of Sidgwick's views. ${ }^{15}$ F. Y. Edgeworth did the same in New and Old Methods of Ethics, and in his Mathematical Psychics: An Essay on the Application of Mathematics to the Moral Sciences he writes that Methods is a 'great work' in which 'the distinction between egoism and utilitarianism has been drawn with matchless skill by Mr. Sidgwick', and that his aim in part is to 'confirm Mr. Sidgwick's proof that Greatest Happiness is the end of right action'. ${ }^{16}$

Deigh claims that 'attention to and interest in the ideas and arguments in Methods greatly diminished after Sidgwick's death' (438). This is, however, hard to accept. In 1901, F. H. Hayward opined that

If thoughts and suggestions can be regarded for the moment as entities capable of enumeration, the Methods of Ethics probably contains a greater number than any other ethical work of the size that has ever been written. It is a rich mine of thought from which moralists will borrow (with or without acknowledgement) for years to come. ${ }^{17}$

He was right. G. E. Moore cited Sidgwick more than any other philosopher in Principia Ethica. ${ }^{18}$ Moore went so far as to claim that 'only one ethical writer', i.e. Sidgwick, avoided committing the naturalistic fallacy. ${ }^{19}$ In Ethics, he reproduced (without acknowledgement) Sidgwick's arguments against definitional or analytical naturalism. ${ }^{20}$ J. M. E. McTaggart wrote the now underappreciated and little read 'The Ethics of Henry Sidgwick'. ${ }^{21}$ Hastings Rashdall devoted considerable attention to Sidgwick's view in his The Theory of Good and Evil. ${ }^{22}$ He was particularly impressed

14 F. H. Bradley, Ethical Studies (Oxford, 1876) and Mr. Sidgwick's Hedonism (London, 1877).

15 Herbert Spencer, The Data of Ethics (London, 1879).

16 F. Y. Edgeworth, New and Old Methods of Ethics (Oxford, 1877) and Mathematical Psychics: An Essay on the Application of Mathematics to the Moral Sciences (London, 1881), pp. 104, 102 and vii (italics in original).

17 F. H. Hayward, The Ethical Philosophy of Sidgwick: Nine Essays, Critical and Expository (London, 1901), p. 15.

18 G. E. Moore, Principia Ethica (Cambridge, 1903).

19 Moore, Principia, p. 17; see also p. 59. The truth of Moore's statement will not concern me here.

20 See G. E. Moore, Ethics (London, 1912), chs. 2-3. W. D. Ross (with acknowledgement) and A. J. Ayer (without acknowledgement) do the same. See W. D. Ross, The Right and The Good (Oxford, 1930), pp. 7-8 and A. J. Ayer, Language, Truth and Logic (London, 1936), ch. 6. For Sidgwick's arguments, see ME, pp. 26-35.

21 J. M. E. McTaggart, 'The Ethics of Henry Sidgwick', Quarterly Review 205 (1906), pp. 398-419.

${ }_{22}$ Hastings Rashdall, The Theory of Good and Evil, 2 vols. (Oxford, 1907). See also Hastings Rashdall, Ethics (London, 1913), where much attention is paid to Sidgwick, 
by Sidgwick's discussion and evaluation of common-sense morality. 'The loose statements of Intuitionists as to the clearness, certainty, adequacy, and self-evidence of the ordinarily received rules of conduct have never been subjected to so searching, so exhaustive, and so illuminating an examination. ${ }^{23}$ In 1908, in a paper comparing aspects of Green and Sidgwick, G. F. Barbour described both Green and Sidgwick as 'rival leaders of English ethical thought'. ${ }^{24} \mathrm{H}$. A. Prichard began writing about him in the 1920 s, though in work that was not at the time published. ${ }^{25}$ In 1928, E. F. Carritt described ME as 'The best exposition of the rationalist or altruistic utilitarian theory. ${ }^{\prime 26}$ In 1934 , W. D. Lamont maintained that 'Any criticism of Utilitarianism would be more incomplete than need be, if it neglected to take account of the development of the principles of that school by Professor Sidgwick. ${ }^{27}$ Lamont chastises C. D. Broad for the derogatory statements he makes about Sidgwick in comparing him to Green: 'No worthy follower of Green would so under-rate Sidgwick's influence'. ${ }^{28} \mathrm{He}$ adds that Sidgwick has 'many distinguished disciples, past and present'. ${ }^{29} \mathrm{He}$ goes on to discuss the quality that gives Sidgwick's work a 'permanent disciplinary value for students of philosophy'; he does not impugn Broad's positive claims about Sidgwick. ${ }^{30}$ In 1939, Ross suggested that he is the 'clearest-headed of the hedonists'. ${ }^{31}$ In the same work Ross cites Sidgwick nearly as many times as he cites Aristotle, Kant, Broad and Moore. ${ }^{32}$ So, pace Deigh, Broad was not the only Englishman who admired Sidgwick's work (439). ${ }^{33}$

and Is Conscience an Emotion? (Boston, 1914), in which Rashdall expresses agreement with many of Sidgwick's doctrines; see pp. 42, 113-14, 128, 130 and 183.

${ }_{23}$ Rashdall, Theory, vol. 1, p. 83.

${ }_{24}$ G. F. Barbour, 'Green and Sidgwick on the Community of the Good', The Philosophical Review 17 (1908), p. 149.

${ }^{25}$ See H. A. Prichard, 'Manuscript on Morals', Moral Writings, ed. Jim MacAdam (Oxford, 2002), pp. 114-62.

${ }^{26}$ E. F. Carritt, The Theory of Morals: An Introduction to Ethical Philosophy (Oxford, 1928), p. 143.

27 W. D. Lamont, Introduction to Green's Moral Philosophy (London, 1934), p. 172.

${ }^{28}$ Lamont, Green's, p. 21. Lamont is referring to Broad's suggestion that Green 'probably made far more undergraduates into prigs than Sidgwick will ever make into philosophers'. See C. D. Broad, Five Types of Ethical Theory (London, 1930), p. 144.

${ }^{29}$ Lamont, Green's, p. 21.

${ }^{30}$ Lamont, Green's, p. 21.

31 W. D. Ross, The Foundations of Ethics (Oxford, 1939), p. 27.

32 A decade and a half later, Ross remarks on the 'careful criticism by Sidgwick' of 'Kant's use of the term "freedom"'. See W. D. Ross, Kant's Ethical Theory (Oxford, 1954), pp. 83-4.

33 See also F. H. Hayward, 'The True Significance of Sidgwick's "Ethics”', International Journal of Ethics 11 (1901), pp. 175-87; E. E. Constance Jones, 'Mr. Hayward's Evaluation of Professor Sidgwick's Ethics', International Journal of Ethics 11 (1901), pp. 354-60; F. H. Hayward, 'A Reply', International Journal of Ethics 11 (1901), pp. 360-65; James Seth, 'The Ethical System of Henry Sidgwick', Mind 10 (1901), pp. 172-87; Ernest Albee, 'An 
Finally, it is dubious to claim that the decline of the epistemology that Sidgwick relied on was the reason for Methods's putative decline. Deigh maintains that Sidgwick subscribed to philosophical intuitionism, the view according to which there are (a) abstract self-evident propositions or intuitions and (b) a set of derivatively justified propositions justified by argumentative appeal to the nonderivatively justified or self-evident propositions. ${ }^{34}$ Deigh argues that this epistemology, the traditional intuitionist conception of epistemology, fell into philosophical disrepute following Sidgwick's death and with it went interest in Methods (439-43). ${ }^{35}$ His argument seems to be as follows. Premiss One: The conception of epistemology to which Sidgwick subscribed was impugned in the domain in which it was held to be most plausible, i.e. mathematics, owing to the development of non-Euclidean geometry and Gödel's second incompleteness result. These developments meant that self-evidence 'ceased to be a property that one needs to attribute to some mathematical propositions in order to explain mathematical knowledge' (445). Premiss Two: If an epistemology loses credibility/is impugned in the domain in which it is thought to be most plausible, then it loses credibility/is impugned in additional domains in which it is utilized. Conclusion: Therefore, because defenders of the sort of epistemology to which Sidgwick appealed could 'no longer invoke it [Euclidian geometry] to substantiate their conception of knowledge' it developed a shady reputation in ethics and with it went concern about Methods (442).

There are three responses to this argument. First, it is far from clear that Sidgwick actually holds to all aspects of the traditional intuitionist conception of knowledge. He does suggest at one point that he thinks one can deduce the rules of common-sense morality from his philosophical intuitions (ME 102). He also claims that he relies on his philosophical intuitions and the intuitionist method to arrive at utilitarianism (ME 388, 406-7). However, when he outlines his philosophical intuitions in Book III of ME, he does not in any

Examination of Professor Sidgwick's Proof of Utilitarianism', The Philosophical Review 10 (1901), pp. 251-60; Henry Barker, 'A Recent Criticism of Sidgwick's Methods of Ethics', The Philosophical Review 11 (1902), pp. 607-13; Bernard Bosanquet, 'Hedonism Among Idealists (I.)', Mind 12 (1903), pp. 202-24; E. E. Constance Jones, 'Professor Sidgwick's Ethics', Proceedings of the Aristotelian Society 4 (1903-4), pp. 32-52; James Seth, A Study of Ethical Principles, 12th edn. (New York, 1911); W. R. Sorley, 'Henry Sidgwick', International Journal of Ethics 11 (1901), pp. 168-74; and A. C. Pigou, 'Some Remarks on Utility', The Economic Journal 13 (1903), pp. 58-63.

${ }^{34}$ For a rival account of Sidgwick's epistemology, see John Rawls, A Theory of Justice (Cambridge, Mass., 1971), p. 51 and J. B. Schneewind, Sidgwick's Ethics and Victorian Moral Philosophy (Oxford, 1977). For an account of Sidgwick's epistemology which has some similarities to Deigh's view, see my 'Henry Sidgwick's Moral Epistemology', Journal of the History of Philosophy (forthcoming).

35 Deigh does not, however, cite anyone who dismisses Methods for this reason. 
strict sense deduce common-sense morality or utilitarianism from them. In fact, he denies that you can (ME 379). This suggests that Sidgwick does not see the relationship between his intuitions and various methods of ethics (e.g. utilitarianism) in the way that Deigh's account of Sidgwick's epistemology suggests. In fact, it is quite difficult to ascertain how Sidgwick's philosophical intuitions figure into the argument for utilitarianism. At best they form part of the argument for the view, which includes a negative argument against common-sense morality and its philosophical counterpart, dogmatic intuitionism, and a Millian-style 'proof'. ${ }^{36}$

Second, it cannot be correct that the rejection of Sidgwick's epistemology contributed to the decline of Methods, for works by E. F. Carritt, W. D. Ross, Hastings Rashdall, G. E. Moore, H. A. Prichard, C. D. Broad, among others, subscribed to a similar epistemology, but did not similarly disappear from philosophical view in that period of time. ${ }^{37}$ Deigh suggests that this is due to the fact that these other thinkers, especially Moore and Ross, "could prop up their theories with metaphysical and psychological theses that were alien to Sidgwick's theory', e.g. that moral properties are non-natural properties and that we have a special moral faculty for intuiting moral facts (443-4). ${ }^{38}$ But this is a poor explanation. How does subscription to these specific views help defenders of the traditional intuitionist epistemology explain 'why one needs to attribute self-evidence to some ethical propositions in order to explain ethical knowledge' (445)? ${ }^{39}$ It is not clear how one can ward off worries about the dubiety of the traditional intuitionist conception of epistemology by adopting a specific metaethical or psychological view, and Deigh does not fully explain how one can do so. ${ }^{40}$ If appeal to self-evidence or intuition is sufficient to impugn an

${ }^{36}$ For an account of Sidgwick's philosophical intuitions and the role they play in his argument for utilitarianism, see my 'Sidgwick's Philosophical Intuitions', Etica \& Politica/Ethics and Politics 10 (2008), pp. 185-209. This paper can be found at $<$ http://www2.units.it/ etica/2008_2/SKELTON.pdf $>$.

37 Whether these philosophers subscribe to all aspects of the traditional intuitionist conception of knowledge is open to dispute, though this will not concern me here.

38 It is far from clear that the differences between Moore and Ross on the one hand and Sidgwick on the other are as stark as Deigh suggests. For a different view, see Thomas Hurka, 'Moore in the Middle', Ethics 113 (2003), pp. 599-628. Sidgwick's denial that moral claims are descriptive of the natural world may be enough, if Deigh is right, to help him avoid the problems that Deigh points out for the traditional intuitionist conception of epistemology.

${ }^{39}$ It is noteworthy that Ross and Prichard claim that there are analogies between mathematical and moral knowledge. See H. A. Prichard, 'Does Moral Philosophy Rest on a Mistake?', Moral Writings, ed. Jim MacAdam (Oxford, 2002), p. 13, and Ross, Good, pp. 32-3.

${ }_{40}$ Deigh discusses the possibility that a Euclidean could insist that her postulates are self-evident even in light of non-Euclidean alternatives. He rejects this move as 'unscientific', since it would entail that we have a 'special faculty for directly 
epistemology, then this should be true regardless of the ontology or psychology to which an individual subscribes. This is confirmed by recent defences of rational intuitionism in general epistemology, where the tack is to defend the view in light of the worries that Deigh raises and only after a full defence of the view raise the issue of the appropriate ontology to which a rational intuitionist should subscribe. ${ }^{41}$

Third, one can reject premiss two of Deigh's argument. One may well accept that the epistemology did not work out in, e.g., geometry and related areas but reject that this implies that it does not work well or plausibly in ethics. Bertrand Russell, one of the individuals whom Deigh lists as an architect of the putative decline of the traditional intuitionist conception of knowledge, presumably thought this at one point. ${ }^{42}$ In 1955 , he declared that there is 'no logical objection to this theory [i.e. ethical intuition], and I am not prepared to reject it decisively'. ${ }^{43}$ He goes on to note that the view has a 'grave drawback', that there is a lack of consensus regarding what we ought to do. $\mathrm{He}$ does not mention the decline of the view in geometry and other areas of mathematics. In the same period those friendly to the Sidgwickian approach to moral epistemology continued to turn out defenses of it. In his Second Thoughts in Moral Philosophy, the later intuitionist A. C. Ewing advances a 'middle way' in metaethics. He eschews reliance on non-natural properties and special faculties but not on intuition or, as he preferred to call it, 'direct cognition'. ${ }^{44} \mathrm{He}$ argues that by direct cognition we are able to cognize that 'certain factual properties or circumstances constitute a reason why certain attitudes ought to

apprehending the nature of physical space' and 'natural science cannot allow appeals to faculties beyond the senses as sources of evidence of the nature of the physical world' (443). His view appears to be that appeals to special faculties in ethics are unproblematic because there is no constraint in ethics on allowing faculties beyond the senses as sources of evidence of the nature of the moral world.

41 See Laurence Bonjour, In Defense of Pure Reason (Cambridge, 1998). Bonjour is a Platonist. He does not hold the view that an appeal to Platonist metaphysics helps him defend the intuitionist epistemology against objections. See Bonjour, p. 158. It should be noted that in contemporary ethics the tack is to defend the traditional intuitionist conception of knowledge in part by renouncing special faculties and nonnatural properties. See, for example, Roger Crisp, 'Sidgwick and the Boundaries of Intuitionism', Ethical Intuitionism: Re-evaluations, ed. Philip Stratton-Lake (Oxford, 2002), pp. 56-75, and Robert Audi, The Good in the Right (Princeton, 2004).

${ }^{42}$ Deigh maintains that Russell believes that the axioms of logic are known intuitively (443). Perhaps Russell's thought is that the problems with the traditional intuitionist conception of knowledge are confined to mathematics.

${ }_{43}$ Bertrand Russell, Human Society in Ethics and Politics (New York, 1955), p. 93; italics in original. In the same place he notes agreement with some of Sidgwick's views; see pp. $96-7$ and 99.

44 A. C. Ewing, Second Thoughts in Moral Philosophy (New York, 1959), p. 66. Around the same time, A. J. Ayer was defending reliance on intuition in both mathematics and logic; see The Problem of Knowledge (London, 1956). At the very least this weakens Deigh's claim about the decline of the traditional intuitionist conception of knowledge. 
be adopted or certain actions done... we see immediately that certain factors constitute a reason' ${ }^{45}$ He does not address the worry that Deigh raises. ${ }^{46}$ Instead, he addresses what he calls 'one of the most popular arguments' against appeal to direct cognition, which is expressed by P. F. Strawson, and is not the sort of worry that Deigh discusses. Perhaps the more likely explanation for the decline of the traditional intuitionist conception of knowledge in ethics (though not Methods) is the popularity of Strawson's attack on it ${ }^{47}$ and the development of a plausible rival account of moral epistemology, i.e. Rawlsian coherentist reflective equilibrium. ${ }^{48}$

askelto4@uwo.ca

45 Ewing, Second Thoughts, p. 66.

46 Nor is the worry addressed in Oliver A. Johnson's defence of an intuitionist position that has much in common with Sidgwick's view. See Oliver A. Johnson, 'Ethical Intuitionism - A Restatement', The Philosophical Quarterly 7 (1957), pp. 193-203. In his defence Johnson appeals to neither special moral faculties nor non-natural properties.

47 P. F. Strawson, 'Ethical Intuitionism', Philosophy 24 (1949), pp. 23-33.

48 I wish to thank Bart Schultz and, especially, Robert Shaver for helpful comments on an earlier draft, the librarians at the Wren Library, Trinity College, Cambridge University and at the Thomas Fisher Rare Book Library, University of Toronto for research assistance, and the University of Western Ontario's Academic Development Fund and International Research Award programmes for generous research support. 